\title{
Antioxidants and selenocompounds inhibit 3,5-dimethylaminophenol toxicity to human urothelial cells
}

\author{
Pinar Erkekoglu ${ }^{1,2}$, Ming-Wei Chao ${ }^{1,3,4}$, Chia-Yi Tseng, ${ }^{4,5}$, Bevin P. Engelward ${ }^{1}$, Ozge Kose², \\ Belma Kocer-Gumusel ${ }^{2}$, Gerald N. Wogan ${ }^{1}$, and Steven R. Tannenbaum ${ }^{1}$ \\ ${ }^{1}$ Department of Biological Engineering, Massachusetts Institute of Technology, Cambridge, MA, USA \\ ${ }^{2}$ Hacettepe University, Faculty of Pharmacy, Department of Toxicology, Ankara, Turkey \\ ${ }^{3}$ Department of Bioscience Technology, College of Science, Chung Yuan Christian University, Zhongli district, \\ Taoyuan, Taiwan \\ ${ }^{4}$ Center of Nanotechnology, Chung Yuan Christian University, Zhongli district, Taoyuan, Taiwan \\ ${ }^{5}$ Department of Biomedical Engineering, College of Engineering, Chung Yuan Christian University, Zhongli district, \\ Taoyuan, Taiwan
}

[Received in June 2018; Similarity Check in June 2018; Accepted in February 2019]

Exposure to alkyl anilines may lead to bladder cancer, which is the second most frequent cancer of the urogenital tract. 3,5-dimethylaniline is highly used in industry. Studies on its primary metabolite 3,5-dimethylaminophenol (3,5-DMAP) showed that this compound causes oxidative stress, changes antioxidant enzyme activities, and leads to death of different mammalian cells. However, there is no in vitro study to show the direct effects of 3,5-DMAP on human bladder and urothelial cells. Selenocompounds are suggested to decrease oxidative stress caused by some chemicals, and selenium supplementation was shown to reduce the risk of bladder cancer. The main aim of this study was to investigate whether selenocompounds organic selenomethionine $(\mathrm{SM}, 10 \mu \mathrm{mol} / \mathrm{L})$ or inorganic sodium selenite $(\mathrm{SS}, 30 \mathrm{nmol} / \mathrm{L})$ could reduce oxidative stress, DNA damage, and apoptosis in UROtsa cells exposed to 3,5-DMAP. 3,5-DMAP caused a dose-dependent increase in intracellular generation of reactive oxygen species, and its dose of $50 \mu \mathrm{mol} / \mathrm{L}$ caused lipid peroxidation, protein oxidation, and changes in antioxidant enzyme activities in different cellular fractions. The comet assay also showed single-strand DNA breaks induced by the 3,5-DMAP dose of $50 \mu \mathrm{mol} / \mathrm{L}$, but no changes in double-strand DNA breaks. Apoptosis was also triggered. Both selenocompounds provided partial protection against the cellular toxicity of 3,5-DMAP. Low selenium status along with exposure to alkyl anilines can be a major factor in the development of bladder cancer. More mechanistic studies are needed to specify the role of selenium in bladder cancer.

KEY WORDS: alkyl anilines; cytotoxicity; genotoxicity; reactive oxygen species; selenium; sodium selenite; selenomethionine

Bladder cancer is the sixth most common cancer in men and the $17^{\text {th }}$ in women. Almost 550,000 new cases were reported in the world in 2018 alone (1-3). It accounts for about $7 \%$ of all cancer incidence in men. In the European Union countries, it is the fourth most common cancer among men (4). Annual incidence is $36 / 100,000$ in men and $10 / 100,000$ in women, and mortality 13/100,000 in men, and 4/100,000 in women. Its incidence and prevalence rise after the age of 60 (5).

Well-established risk factors are tobacco consumption, occupational exposure (particularly to monocyclic aromatic amines and polycyclic aromatic hydrocarbons), and infection with Schistosoma hematobium $(6,7)$. Other risk factors include alcohol consumption, high coffee consumption, low fruit and vegetable consumption, low vitamin and trace element intake (low selenium and vitamin

Corresponding author: Pinar Erkekoglu, Associate Professor, Department of Toxicology, Hacettepe University Faculty of Pharmacy, Ankara, Turkey, E-mail:erkekp@yahoo.com; erkekp@hacettepe.edu.tr
E intake in particular), exposure to drinking water contaminated with environmental chemicals, and some medical treatments (7-9).

Exposure to environmental alkyl amines/alkyl anilines, aniline dyes, and other aromatic amines, which originate from multiple sources, is also a well-documented risk factor for this disease. For example, tobacco smoke, which contains high levels of aromatic amines, increases the risk of bladder cancer from two to five times (1). These chemicals are also present in hair dyes, combustion products, pharmaceuticals, and pesticides (8).

Workers exposed to o-toluidine, aniline, and nitrobenzene at a rubber chemical manufacturing plant in New York had nearly three times higher bladder cancer incidence than the New York State general population. Smoking habits were suggested to account for only $8 \%$ higher bladder cancer incidence in that cohort (7). A nonoccupational epidemiological study in the Los Angeles County showed that 2,6-dimethylaniline (2,6-DMA), 
3,5-dimethylaniline (3,5-DMA), and 3-ethylaniline (3-EA), were significantly associated with bladder cancer incidence, regardless of smoking (10).

3,5-dimethylaniline is used in the production of azo dyes, pharmaceuticals, antioxidants, detergents, wood preservatives, textiles, metal complexes, and antiozonants (8). Like other aromatic amines, 3,5-DMA is metabolised by cytochrome P450 enzymes (CYP450) through $\mathrm{N}$-hydroxylation. N-hydroxy-3,5-dimethylaniline $(\mathrm{N}-\mathrm{OH}-$ 3,5-DMA) is a direct mutagen, supporting the evidence that $\mathrm{N}$-hydroxylation of such compounds is a bio-activation step. The parent compound, 3,5-DMA, has also been shown to bind to DNA in laboratory animals, but there is no sufficient evidence of DNA adduct formation in humans (11). 3,5-dimethylaminophenol (3,5-DMAP), in turn, is either a product of 3,5-DMA oxidation or a N-OH-3,5-DMA hydroxylation metabolite catalysed by CYP450.3,5-DMAP can be metabolised into 3,5-dimethylquinone imine (3,5DMQI), which undergoes further redox cycling, whose by-products are reactive oxygen species (ROS), $\mathrm{H}_{2} \mathrm{O}_{2}$ and hydroxyl $(\bullet \mathrm{OH})$ radicals in particular $(12)$.

In our earlier studies (11-14), 3,5-DMAP induced ROS production, cytotoxicity, and genotoxicity in Chinese hamster ovary $(\mathrm{CHO})$ cells. It also up-regulated caspase 3 and 8 activities and activated apoptosis.

If not counteracted by antioxidants and intracellular antioxidant systems, ROS damages important cellular molecules, including proteins, lipids, and DNA (15). Low antioxidant levels, low selenium in particular, increase the risk of several types of malignancies, including bladder cancer $(16,17)$. Selenium is a component of several antioxidant enzymes, namely glutathione peroxidases (GPx) and thioredoxin reductases (TrxR) $(18,19)$. We have previously shown that organic and inorganic selenium protect against oxidative stress produced by a wide variety of chemicals $(20,21)$.

Recently, we found that $N$-acetylcysteine (NAC), ascorbic acid (Asc), and selenocompounds protect modified CHO cells, including gpt-transgenic As52, aprt-transgenic AA8, and aprt-transgenic/NER-deficient UV5 cells, from oxidative damage caused by 3,5-DMAP (12-14). However, no effects of alkyl amine/alkyl aniline metabolites on the UROtsa cells have been examined so far. Considering that the urothelium is one of the targets of aromatic amineinduced carcinogenesis, we conducted this study to evaluate the protective effects of inorganic selenium (sodium selenite, SS) and organic selenium (selenomethionine, SM) against the cytotoxic, oxidant, and genotoxic properties of 3,5-DMAP in UROtsa cells. Additionally, we assessed the protective effects of ascorbic acid (Asc) and $N$-acetylcysteine (NAC) against the cytotoxic and ROS-inducing action of 3,5-DMAP.

\section{MATERIALS AND METHODS}

\section{Chemicals and reagents}

All chemicals, including SS, SM, and the protease inhibitor cocktail, were purchased from Sigma-Aldrich (St. Louis, MO, USA). All cell culture reagents were purchased from Lonza (Walkersville, MD, USA) or Sigma-Aldrich. Molten normal melting point agarose, low melting point agarose, and fluorescence dyes SYBR Gold and Hoechst 33258 were purchased from Molecular Probes/Invitrogen (Eugene, OR, USA). GelBond film was obtained from Lonza. Bottomless 96-well plates for the comet assay were purchased from Greiner BioOne (Monroe, NC, USA).

\section{Kits}

Nuclear and cytoplasmic extraction kits were purchased from Thermo Fisher Scientific (Rockford, IL, USA). Cell proliferation reagent (2-(4-iodophenyl)- 3-(4-nitrophenyl)5-(2,4-disulfophenyl)-2H tetrazolium, monosodium salt) (WST-1) kit was purchased from Roche Applied Science (Indianapolis, IN, USA). 5-(and 6-) chloromethyl-2',7'dichlorodihydrofluorescein diacetate (CM- $\left.\mathrm{H}_{2} \mathrm{DCFA}\right) \mathrm{ROS}$ detection kit was from Molecular Probes/Invitrogen. All other assay kits were from Sigma-Aldrich, except the thiobarbituric acid reactive substance (TBARS) and carbonyl assay kits (Cayman Chemical Company, Ann Arbor, MI, USA).

\section{Synthesis of 3,5-dimethyaminophenol}

3,5-DMAP was synthesised in our lab as described by Chao et al. (12). Briefly, a mixture of sulphanilic acid, sodium carbonate, and water was heated to $60^{\circ} \mathrm{C}$ and then cooled in an ice bath. Sodium nitrite solution was added, and the resulting solution was poured on $\mathrm{HCl}$ solution (aqueous, 5.6\% w/v) in an ice bath and kept for $15 \mathrm{~min}$. This solution was added to 2,6-dimethylphenol solution (in aqueous $\mathrm{NaOH}$ and water) at $5{ }^{\circ} \mathrm{C}$. The dark red reaction mixture was stirred well and kept at $25^{\circ} \mathrm{C}$ for $1 \mathrm{~h}$. Later, it was heated to $60{ }^{\circ} \mathrm{C}$, and aqueous sodium hydrosulphite $(1 \% \mathrm{w} / \mathrm{v})$ was gradually added till yellow crystals were precipitated. After waiting for $15 \mathrm{~min}$ at $50{ }^{\circ} \mathrm{C}$, the yellow suspension was cooled to $20^{\circ} \mathrm{C}$ and then filtered. The filtrate was then washed with sodium hydrosulphite $(1 \% \mathrm{w} / \mathrm{v}$ in water) and dried under vacuum. The final yield of 3,5DMAP was $82 \%$.

\section{Cell culture and treatment}

Cells of the UROtsa line were obtained from Thermo Fischer Scientific. UROtsa line is a primary culture of normal human urothelium isolated through immortalisation with a construct containing the SV40 large T antigen. In Dulbecco's Modified Eagle's Medium (DMEM) cells were grown as a monolayer in plastic flasks, containing foetal bovine serum (FBS, 5\%, v/v) and glucose $(1 \mathrm{mg} / \mathrm{mL})$. The 
cells were fed on fresh medium every three days and grown until reaching about $90 \%$ confluence. Confluent cultures were subcultured at a 1:4 ratio in a humidified atmosphere with $5 \% \mathrm{CO}_{2}$ at $37{ }^{\circ} \mathrm{C}$. Prior to all experiments, UROtsa cells were cultured with a 1:1 mixed serum-free medium of DMEM and Ham's F-12, supplemented with insulin $(5 \mu \mathrm{g} / \mathrm{mL})$, hydrocortisone $(36 \mathrm{ng} / \mathrm{mL})$, and EGF (10 ng/ $\mathrm{mL})$ for two days. For the experiments UROtsa cells $\left(10^{6}\right)$ were plated in plastic flasks. After exposure, they were trypsinised and held at $-80{ }^{\circ} \mathrm{C}$ until preparation of cytoplasmic and nuclear fractions. Cells exposed to 3,5DMAP for $1 \mathrm{~h}$ were washed twice with fresh serum-free medium and then incubated in a fresh medium at $37^{\circ} \mathrm{C}$ for another $24 \mathrm{~h}$

The experimental design is described in Table 1. Our preliminary 3,5-DMAP cytotoxicity experiments on the UROtsa cells included a wide dose range $(1-1000 \mu \mathrm{mol} / \mathrm{L})$ for several reasons. One was to determine the half-maximal inhibitory concentration $\left(\mathrm{IC}_{50}\right)$ for cell viability, and the other was to follow producers' kit protocol recommendations for one-hour exposure in the ROS experiments. The $\mathrm{IC}_{50}$ was determined to be $100 \mu \mathrm{mol} / \mathrm{L}, \mathrm{IC}_{70} 50 \mu \mathrm{mol} / \mathrm{L}$, and $\mathrm{IC}_{80}$ $25 \mu \mathrm{mol} / \mathrm{L}$. As the $\mathrm{IC}_{80}(25 \mu \mathrm{mol} / \mathrm{L})$ did not cause significant effects on oxidative stress parameters on the UROtsa cells, we selected the $\mathrm{IC}_{70}$ dose $(50 \mu \mathrm{mol} / \mathrm{L})$ for all subsequent experiments.

The Asc and NAC ( \pm DMAP) treated groups were used for cytotoxicity and ROS assessments, while the SS and SM ( \pm DMAP) groups were used for cytotoxicity, ROS, antioxidant parameter, apoptosis, and genotoxicity measurements.

The concentrations of SS and SM were chosen from preliminary experiments considering maximum glutathione peroxidase 1 (GPx1) induction (20-25). They were in the same ranges that were applied previously for several other cell types. The concentration of Asc and NAC was chosen based on our previous studies (10-12).

Exposure times of 24 and $72 \mathrm{~h}$ were also based on our previous studies with 3,5-DMAP $(13,14)$. Because the results obtained from the 24- and 72-hour treatment groups of both SS and SM were similar in most parameters measured, only the 24-hour results are included in the Results section.

\section{Nuclear and cytoplasmic extract preparation}

After centrifugation at $500 \times g$ for $5 \mathrm{~min}$, cell pellets were washed with PBS and re-centrifuged at $500 \times g$ for $3 \mathrm{~min}$. The supernatant was discarded and the obtained dry pellet used to obtain nuclear and cytoplasmic cellular fractions using a nuclear and cytoplasmic extraction kit (in the presence of a protease inhibitor cocktail).

\section{Determination of cytotoxicity}

The cytotoxicity assay was performed with a WST-1 kit. After treatment, the cells were washed with PBS, suspended in $1 \mathrm{~mL}$ of fresh medium, and then pipetted into 96-well plates. WST-1 was added to each well, and the cells incubated in the dark at $37^{\circ} \mathrm{C}$ for $1 \mathrm{~h}$.

Formazan absorbance was quantified with a spectrophotometer (SpectraMax ${ }^{\circledR}$ Microplate Reader, Molecular Devices, San Francisco, CA, USA) at $495 \mathrm{~nm}$ and SoftMax Pro software (Molecular Devices, Sunnyvale, CA). ROS production in the cells was adjusted to negative control (assuming their ROS production as 100\%).

\section{Quantification of intracellular ROS}

Intracellular ROS was detected with a CM- $\mathrm{H}_{2}$ DCFA ROS detection kit, which dyes living cells in fluorescent green.

The cells of either group were washed with PBS and suspended in $1 \mathrm{~mL}$ wells with serum-free medium. Cell suspension solutions were pipetted into 96-well plates and mixed with DMEM containing CM- $\mathrm{H}_{2}$ DCFDA (final concentration in each well: $25 \mu \mathrm{mol} / \mathrm{L}$ ), activated by preincubation at $37^{\circ} \mathrm{C}$ for $30 \mathrm{~min}$. Generated ROS was detected immediately on a SpectraMax ${ }^{\circledR}$ Microplate Reader $\left(\lambda_{\text {excitation }}\right.$ :

Table 1 Experimental design

\begin{tabular}{|c|c|c|}
\hline Experimental groups of UROtsa cells & Pretreatment & Treatment \\
\hline Control $^{\#}$ & - & - \\
\hline SS & & $\mathrm{SS}(30 \mathrm{nmol} / \mathrm{L})$ for $24 \mathrm{~h}$ \\
\hline SM & & $\mathrm{SM}(10 \mu \mathrm{mol} / \mathrm{L})$ for $24 \mathrm{~h}$ \\
\hline DMAP & & 3,5 -DMAP $(50 \mu \mathrm{mol} / \mathrm{L})$ for $1 \mathrm{~h}^{*}$ \\
\hline SS/DMAP & $\mathrm{SS}(30 \mathrm{nmol} / \mathrm{L})$ for $24 \mathrm{~h}$ & 3,5-DMAP $(50 \mu \mathrm{mol} / \mathrm{L})$ for $1 \mathrm{~h} *$ \\
\hline SM/DMAP & $10 \mu \mathrm{mol} / \mathrm{L} \mathrm{SM}$ for $24 \mathrm{~h}$ & 3,5 -DMAP $(50 \mu \mathrm{mol} / \mathrm{L})$ for $1 \mathrm{~h}^{*}$ \\
\hline Asc & & Asc $(50 \mathrm{mg} / \mathrm{mL})$ for $24 \mathrm{~h}$ \\
\hline Asc/DMAP & Asc $(50 \mathrm{mg} / \mathrm{mL})$ for $24 \mathrm{~h}$ & 3,5-DMAP $(50 \mu \mathrm{mol} / \mathrm{L})$ for $1 \mathrm{~h}^{*}$ \\
\hline NAC & & $\mathrm{NAC}(5 \mathrm{mmol} / \mathrm{L})$ for $24 \mathrm{~h}$ \\
\hline NAC/DMAP & $\mathrm{NAC}(5 \mathrm{mM})$ for $24 \mathrm{~h}$ & 3,5 -DMAP $(50 \mu \mathrm{mol} / \mathrm{L})$ for $1 \mathrm{~h}^{*}$ \\
\hline
\end{tabular}


$485 \mathrm{~nm}, \lambda_{\text {emission }}: 530 \mathrm{~nm}$ ) and quantified with SoftMax Pro software. ROS production was adjusted to negative control.

\section{Determination of antioxidant enzyme activities}

The activity of GPx1, a selenoenzyme mediating lipid peroxide and $\mathrm{H}_{2} \mathrm{O}_{2}$ reduction was measured with a respective Sigma Aldrich kit (see above) (18). TrxR activity was determined with an activity assay kit which can measure the reduction of the substrate 5,5'-dithiobis(2nitrobenzoic) acid (DTNB) to 5-thio-2-nitrobenzoic acid (TNB) at $412 \mathrm{~nm}$ (19). Catalase (CAT) activity was determined with a colorimetric assay kit by measuring the enzymatic decomposition of $\mathrm{H}_{2} \mathrm{O}_{2}$ at $520 \mathrm{~nm}$. Total superoxide dismutase (SOD) activity was measured with a total SOD activity kit. The inhibition of SOD activity was determined colorimetrically by measuring the reduction in the color development at $440 \mathrm{~nm}$.

Glutathione reductase (GR) activity was determined with a GR activity assay kit. This assay mainly depends on the reduction of GSSG in the presence of NADPH, DTNB, and GR. Glutathione-S-transferase activity was determined with an assay kit using 1-chloro-2,4 dinitrobenzene (CDNB) as a substrate at $340 \mathrm{~nm}$ according to Habig et al. (26).

\section{Determination of total, reduced, and oxidised glutathione levels}

Total glutathione (GSH) concentrations of different cellular compartments were determined with a total glutathione assay kit. For the quantification of GSSG, reduced GSH was blocked by the addition of 2-vinylpyridine in the presence of triethanolamine. GSH concentrations were calculated using the following equation: $\mathrm{GSH}=$ (total GSH-2xGSSG). Cytoplasmic and nuclear redox ratio ([GSH]/[GSSG]) was calculated by dividing the GSH concentration with the GSSG concentration.

\section{Determination of lipid peroxidation}

Lipid peroxidation in nuclear and cytoplasmic extracts was quantified by measuring the concentration of thiobarbituric acid reactive substance (TBARS) spectrofluorometrically using a TBARS assay kit (27), as it reflects malondialdehyde (MDA) concentrations, and the results were expressed as $\mu \mathrm{mol} / \mathrm{g}$ of protein.

\section{Determination of protein oxidation}

The most commonly used indicator of protein oxidation is protein carbonyl content (28), which was measured with a carbonyl assay kit at $360 \mathrm{~nm}$ spectrophotometrically.

\section{Total protein determination}

Protein content of the samples was determined with the bicinchoninic acid (BCA) protein assay kit. The absorbance values of the samples were measured at $562 \mathrm{~nm}$, and the results expressed as $\mathrm{mg} / \mathrm{mL}$ (29).

\section{Determination of caspase 3 and caspase 8 activities}

Caspase 3 activity was measured with a colorimetric assay kit based on hydrolysis of the peptide substrate acetylAsp-Glu-Val-Asp p-nitroanilide (AcDEVD-pNA), which results in release of the p-nitroaniline (pNA) moiety. Total pNA released from the substrate was calculated from the absorbance values at $405 \mathrm{~nm}$ or from a calibration curve obtained from pNA standards.

Caspase 8 activity was also measured with a colorimetric assay kit based on the hydrolysis of the peptide substrate Acetyl-Ile-Glu-Thr-Asp p-nitroaniline (Ac-IETDpNA), which results in the release of a pNA moiety. Total pNA released from the substrate was determined from the absorbance values at $405 \mathrm{~nm}$ or from a standard pNA calibration curve.

\section{Comet assay}

Comet assay is a sensitive, fast, and flexible method that can easily detect DNA damage caused by environmental chemicals on different cell types. It is also useful in evaluating the ability of antioxidants/micronutrients to protect the integrity of the genetic material (30). The CometChip protocol, first described by Wood et al. (31), is gaining significant importance for high throughput DNA damage analysis.

Single strand breaks (SSBs) were determined using the alkaline CometChip protocol, while double strand breaks (DSBs) were detected using the neutral CometChip protocol. Briefly, for SSB determination, treated UROtsa cells $\left(100 \mu \mathrm{L}, 10^{6}\right.$ cells $\left./ \mathrm{mL}\right)$ were pipetted into a bottomless 96-well plate and captured by gravity. The plate was then removed and the gel covered with $1 \%$ low melting point agarose. The cells were loaded to CometChips and lysed in a lysis buffer. This buffer consisted of $0.3 \mathrm{~mol} / \mathrm{L} \mathrm{NaOH}$, $2.5 \mathrm{~mol} / \mathrm{L} \mathrm{NaCl}, 10 \mathrm{mmol} / \mathrm{L}$ Tris, $1 \%$ Triton $\mathrm{X}$, and $1 \mathrm{mmol} / \mathrm{L} \mathrm{Na} \mathrm{NaDTA}_{2}$. After overnight lysis, they were electrophoresed in a cold alkaline electrophoresis buffer ( $0.3 \mathrm{~mol} / \mathrm{L} \mathrm{NaOH}$ and $1 \mathrm{~m} \mathrm{~mol} / \mathrm{L} \mathrm{Na}_{2}$ EDTA) at $4{ }^{\circ} \mathrm{C}$ for $40 \mathrm{~min}$. The chips were then neutralised twice in fresh buffer $(0.4 \mathrm{~mol} / \mathrm{L} \mathrm{Tris}-\mathrm{HCl}$ at $\mathrm{pH} 7.5)$ at $4{ }^{\circ} \mathrm{C}$ for $15 \mathrm{~min}$ and stained with SYBR Gold according to the manufacturer's instructions for fluorescence imaging. Images were captured using a Nikon $80 \mathrm{i}$ upright microscope (Nikon Instruments, Tokyo, Japan) coupled with an automatic scanning system and analysed with a customised Guicometanalyzer software by MATLAB (The Mathworks, Natick, MA, USA).

For DSB determination, the gels were lysed in a neutral lysis buffer [2.5 $\mathrm{mol} / \mathrm{L} \mathrm{NaCl}, 2 \mathrm{mmol} / \mathrm{L} \mathrm{Na}_{2}$ EDTA, $10 \mathrm{mmol} / \mathrm{L}$ Tris, $1 \% \mathrm{~N}$-lauroylsarcosine, $\mathrm{pH} 9.5$ with $0.5 \%$ Triton X-100, and 10\% dimethyl sulphoxide (DMSO) added $20 \mathrm{~min}$ before use] at $43^{\circ} \mathrm{C}$ for $4 \mathrm{~h}$. Chips were then washed three times with the electrophoresis buffer $(90 \mathrm{mmol} / \mathrm{L}$ Tris, $90 \mathrm{mmol} / \mathrm{L}$ boric acid, and $2 \mathrm{mmol} / \mathrm{L} \mathrm{Na}_{2}$ EDTA, $\mathrm{pH}$ 8.5) for $30 \mathrm{~min}$ and electrophoresed at $4{ }^{\circ} \mathrm{C}$ for $1 \mathrm{~h}$. After neutralisation, the CometChips were stained with SYBR 
Gold for fluorescence imaging. Images were captured and analysed in the same manner as with the alkaline CometChip protocol. For DNA damage parameters we took \%tail DNA as the level of DNA damage and olive tail moment (OTM, which represents the product of comet length and tail intensity).

Untreated cells were used as controls, cells treated with $\mathrm{H}_{2} \mathrm{O}_{2}(100 \mu \mathrm{mol} / \mathrm{L})$ as positive control, and cells treated with 1\% DMSO as solvent control. All experiments were done in at least triplicate for each group.

\section{Statistical analysis}

The results obtained from triplicate measurements were expressed as mean \pm standard deviation (SD) and analysed with the Statistical Package for Social Sciences Program (SPSS) version 17.0 (Chicago, IL, USA) to compare the study groups. Differences between the groups were evaluated with the Kruskal-Wallis one-way analysis of variance (ANOVA) and later with the Mann Whitney U-test. $P$ values below 0.05 were considered statistically significant.

\section{RESULTS AND DISCUSSION}

\section{Cytotoxicity and ROS production caused by 3,5-DMAP and protection by antioxidants}

Treatment of UROtsa cells with SS, SM, Asc, or NAC alone caused no detectable cytotoxicity, whereas 3,5-DMAP caused a dose-dependent increase in cytotoxicity.
All antioxidants protected the cells against cytotoxicity caused by 3,5-DMAP (Figure 1). 3,5-DMAP significantly increased intracellular ROS generation, and all antioxidants lowered it significantly. Asc and NAC provided almost full protection, and SS and SM only partial protection (Figure 2). At the $\mathrm{IC}_{50}$ of 3,5-DMAP, SS pretreatment restored cell viability to $100 \%$, and SM increased it to $95 \%$. All the oxidant and antioxidant parameters were also detected in the nucleus but were two to nine times lower than in the cytoplasm.

Similar protective properties of SS and SM against the cytotoxic and ROS-producing effects of 3,5-DMAP were also found in AS52 CHO cells. However, the $\mathrm{IC}_{50}$ of 3,5DMAP in AS52 CHO cells was one quarter of ours, $25 \mu \mathrm{mol} / \mathrm{L}(13,14)$. Considering our previous findings, we believe that UROtsa cells are more resistant to the cytotoxic effects of 3,5-DMAP, perhaps because the UROtsa cells are derived from primary cells and then immortalised. However, even though human urothelial cells have a higher $\mathrm{IC}_{50}$ than different strains of $\mathrm{CHO}$ cells, in real life urothelial cells are exposed to many other chemicals and their metabolites besides alkyl aniline metabolites, and their combined effects may lead to carcinogenic changes. These combined effects should be investigated in future studies.

\section{Selenoenzymes}

Selenoenzymes, GPxs in particular, protect cells from oxidative damage caused by peroxides (18). TrxRs are responsible for the reduction of thioredoxin, which is a very

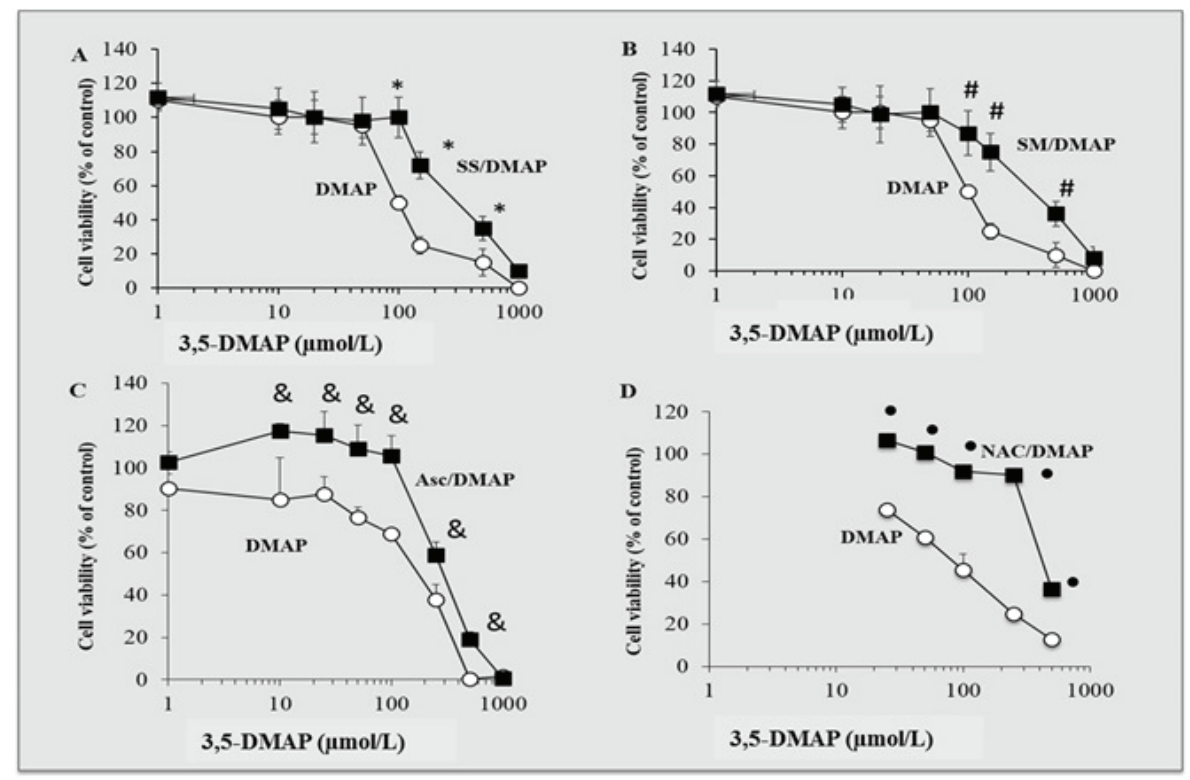

Figure 1 Cell viability expressed in the percentage of control. Values are given as means \pm SD of duplicate measurements of three flasks per group; 3,5-DMAP - 3,5-dimethylaminophenol; SM - selenomethionine; $\mathrm{SS}$ - sodium selenite; $\mathrm{A}$ - cell viability after exposure to 3,5-DMAP for $1 \mathrm{~h}$ (DMAP) or in the group pretreated with SS for $24 \mathrm{~h}$ and then treated with 3,5-DMAP for $1 \mathrm{~h}$ (SS/DMAP); B cell viability after exposure to 3,5-DMAP for $1 \mathrm{~h}$ (DMAP) or in the group pretreated with SM for $24 \mathrm{~h}$ and then with 3,5-DMAP for $1 \mathrm{~h}$ (SM/DMAP); $\mathrm{C}$ - cell viability after exposure to 3,5-DMAP for $1 \mathrm{~h}$ (DMAP) or in the group pretreated with ascorbic acid (Asc) for $24 \mathrm{~h}$ and then with 3,5-DMAP for $1 \mathrm{~h}$ (Asc/DMAP); D: cell viability after exposure to 3,5-DMAP for $1 \mathrm{~h}$ (DMAP) or in the group pretreated with $N$-acetylcysteine (NAC) for $24 \mathrm{~h}$ and then with 3,5-DMAP for $1 \mathrm{~h}$ (NAC/DMAP); ${ }^{*},{ }^{*} \&$, and ${ }^{*}$ - significantly higher than $\operatorname{DMAP}(\mathrm{p}<0.05)$ 
Table 2 Cytoplasmic and nuclear selenoenzyme activities in UROtsa cells

\begin{tabular}{lcccc} 
& \multicolumn{2}{c}{ Cytoplasmic } & \multicolumn{2}{c}{ Nuclear } \\
\cline { 2 - 5 } & $\begin{array}{c}\text { GPx1 } \\
\text { (U/mg protein) }\end{array}$ & $\begin{array}{c}\text { TrxR } \\
\text { (mU/mg protein) }\end{array}$ & $\begin{array}{c}\text { GPx1 } \\
\text { (U/mg protein) }\end{array}$ & $\begin{array}{c}\text { TrxR } \\
\text { (mU/mg protein) }\end{array}$ \\
\hline Control & $0.221 \pm 0.012$ & $0.468 \pm 0.012$ & $0.056 \pm 0.001$ & 0.0660 .003 \\
\hline SS & $0.347 \pm 0.015^{*}$ & $0.691 \pm 0.056^{*}$ & $0.071 \pm 0.004^{*}$ & $0.098 \pm 0.005^{*}$ \\
\hline SM & $0.326 \pm 0.029^{*}$ & $0.698 \pm 0.061^{*}$ & $0.067 \pm 0.002^{*}$ & $0.091 \pm 0.011^{*}$ \\
\hline DMAP & $0.127 \pm 0.018^{*, \#, \&}$ & $0.316 \pm 0.042^{*, \#, \&}$ & $0.034 \pm 0.001^{*, \#, \&}$ & $0.041 \pm 0.010^{*, \#, \&}$ \\
\hline SS/DMAP & $0.199 \pm 0.016$ & $0.567 \pm 0.048$ & $0.052 \pm 0.002$ & $0.065 \pm 0.005$ \\
\hline SM/DMAP & $0.213 \pm 0.019$ & $0.521 \pm 0.064$ & $0.058 \pm 0.003$ & $0.059 \pm 0.012$
\end{tabular}

DMAP - 3,5-dimethylaminophenol (one-hour treatment with the $\mathrm{IC}_{70}$ dose of $50 \mu \mathrm{mol} / \mathrm{L}$ ); GPx1: glutathione peroxidase 1; SS - 24hour pretreatment with sodium selenite; SM - 24-hour pretreatment with selenomethionine; TrxR - thioredoxin reductase; Values are given as means \pm SD of duplicate measurements of three flasks per group; ${ }^{*}$ significantly different from control $(\mathrm{p}<0.05) ;{ }^{*}$ significantly different from the SS/DMAP group $(\mathrm{p}<0.05) ;{ }^{\&}$ significantly different from the $\mathrm{SM} / \mathrm{DMAP}$ group $(\mathrm{p}<0.05)$

important protein in many biological processes, including redox signalling (19). Cytoplasmic and nuclear selenoenzyme activities are summarised in Table 2. As expected, both SS and SM treatments significantly increased GPx1 and TrxR activities in both the cytoplasm and nucleus. 3,5-DMAP treatment, in turn, lowered them significantly. Combined SS and SM treatment with 3,5-DMAP resulted in significant restoration of cytoplasmic and nuclear GPx1 and TrxR activities to nearly control levels.

These and similar drops in GPx1 and TrxR activities in our previous studies may be related to lower expression of these antioxidant proteins but also to post-translational modification caused by 3,5-DMAP exposure. Further mechanistic studies are needed to investigate post- transcriptional or post-translational effects of alkyl anilines and their metabolites on selenoproteins. Moreover, selenoprotein P expression/level should also be measured in vivo after applying 3,5-dimethylaniline, as it is the most important antioxidant selenoprotein in eukaryotic plasma, epithelial, and endothelial cells.

\section{Antioxidant enzymes}

One-hour exposure to $50 \mu \mathrm{mol} / \mathrm{L}$ of 3,5 -DMAP exposure led to substantial changes in cellular antioxidant/ oxidant parameters in UROtsa cells, indicating a shift in the redox equilibrium towards oxidation. Table 3 shows the activities of cytoplasmic and nuclear antioxidant enzymes.

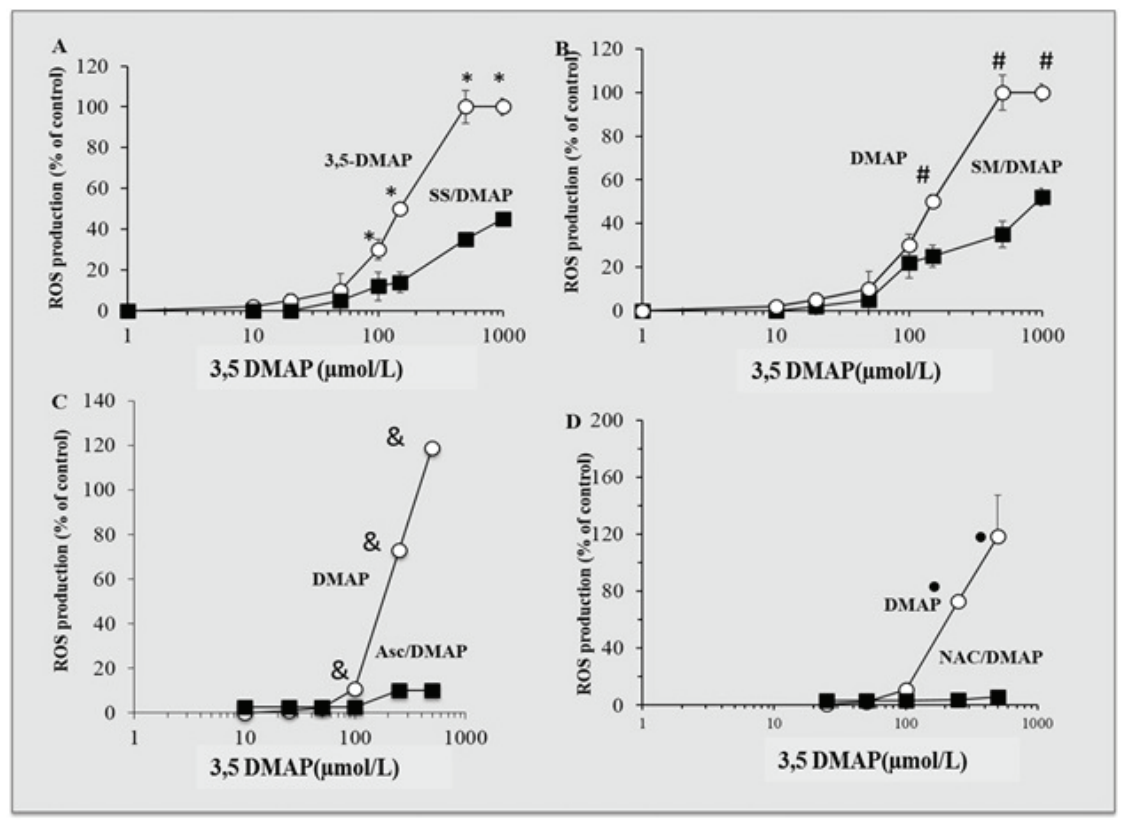

Figure 2 Intracellular ROS production expressed in the percentage of control. Values are given as means $\pm \mathrm{SD}$ of duplicate measurements of three flasks per group; 3,5-DMAP - 3,5-dimethylaminophenol; SM - selenomethionine; SS - sodium selenite; A - ROS production after exposure to 3,5-DMAP for $1 \mathrm{~h}$ (DMAP) or in the group pretreated with $\mathrm{SS}$ for $24 \mathrm{~h}$ and then treated with 3,5-DMAP for $1 \mathrm{~h}$ (SS/ DMAP); B: ROS production after exposure to 3,5-DMAP for $1 \mathrm{~h}$ (DMAP) or in the group pretreated with SM for $24 \mathrm{~h}$ and then with 3,5-DMAP for $1 \mathrm{~h}$ (SM/DMAP); C: ROS production after exposure to 3,5-DMAP for $1 \mathrm{~h}$ (DMAP) or in the group pretreated with ascorbic acid (Asc) for $24 \mathrm{~h}$ and then with 3,5-DMAP for $1 \mathrm{~h}$ (Asc/DMAP); D: ROS production after exposure to 3,5-DMAP for $1 \mathrm{~h}$ (DMAP) or in the group pretreated with $N$-acetylcysteine (NAC) for $24 \mathrm{~h}$ and then with 3,5-DMAP for $1 \mathrm{~h}$ (NAC/DMAP); *, \#, \&, and $\cdot$ - significantly lower than DMAP $(\mathrm{p}<0.05)$ 


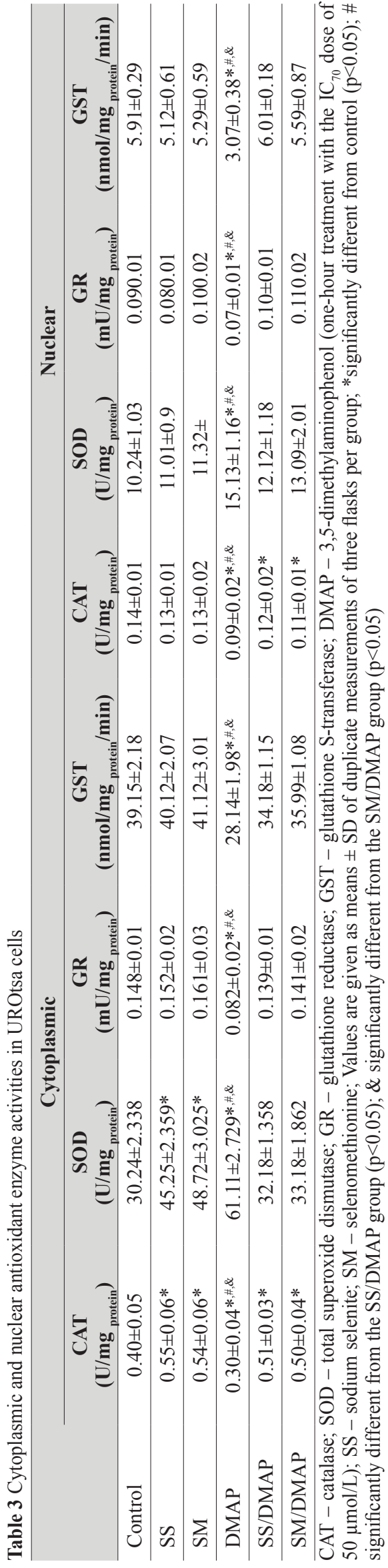

3,5-DMAP significantly lowered both cytoplasmic and nuclear GPx1 and TrxR activities, which was counteracted by SS and SM treatment (Table 3). The same phenomenon was also observed in AA8 and AS52 CHO cells $(13,14)$.

SS and SM treatment significantly increased the cytoplasmic, but not nuclear CAT and SOD activities. DMAP exposure significantly decreased cytoplasmic CAT (35\%), GR (45\%), and GST (28\%) activities and caused a significant (twofold) increase in cytoplasmic SOD activity. 3,5-DMAP treatment also significantly decreased nuclear CAT (36\%), GR (22\%), and GST (48\%) activities. Nuclear SOD activity dropped 1.5 times $(\mathrm{p}<0.05)$.

Almost the same results were previously found in AA8 and AS52 CHO cells (12-14), which clearly points to 3,5DMAP causing an imbalance between cellular enzymatic antioxidants and cellular oxidants in different eukaryotic cells. This needs to be confirmed by future in vivo experiments, which should also establish the expression of enzymatic antioxidants.

\section{Total, oxidised, and reduced glutathione levels}

Cellular thiols, GSH in particular, play an important role in maintaining cellular redox status (32). The effects of 3,5-DMAP $(50 \mu \mathrm{mol} / \mathrm{L})$ on total, oxidised, and reduced GSH levels and intracellular redox ratios are summarised in Table 4. DMAP significantly lowered total GSH levels in the cytoplasm compared to control. In the SS/DMAP and SM/DMAP treatment groups (data not shown for $72 \mathrm{~h}$ groups because there were no differences between 24 -hour and 72-hour treatment) total GSH levels were significantly higher than in the DMAP alone group. 3,5-DMAP increased cytoplasmic GSSG levels 2.3 times $(\mathrm{p}<0.05)$. In cells pretreated with SS and SM they dropped significantly but not to control levels. The cytoplasmic redox ratio was significantly higher in the groups treated with SS and SM alone than in controls $(p<0.05)$. 3,5-DMAP decreased the redox ratio 2.7 times. Nuclear total GSH levels increased significantly in the SS and SM groups and decreased significantly (1.6 times) in the DMAP group. In the SS/ DMAP and SM/DMAP groups, total GSH levels were significantly higher than in the DMAP group.

Due to decreases in total GSH levels in the DMAP alone group, nuclear GSSG levels were lower than control $(\mathrm{p}<0.05)$. Nuclear redox ratio was significantly higher in the SS and SM groups. 3,5-DMAP lowered the ratio 2.7 times $v s$. control while pretreatment with SS and SM restored the ratio to control levels.

\section{Lipid peroxidation and protein oxidation}

Data regarding lipid peroxidation (TBARS) and protein oxidation are also given in Table 4. Cytoplasmic lipid peroxidation levels were 6.6 times higher in the DMAP group $(50 \mu \mathrm{mol} / \mathrm{L}) v s$. control $(\mathrm{p}<0.05)$. Pretreatment with SS and SM decreased lipid peroxidation significantly, but cytoplasmic lipid peroxidation levels in the SS/DMAP and 


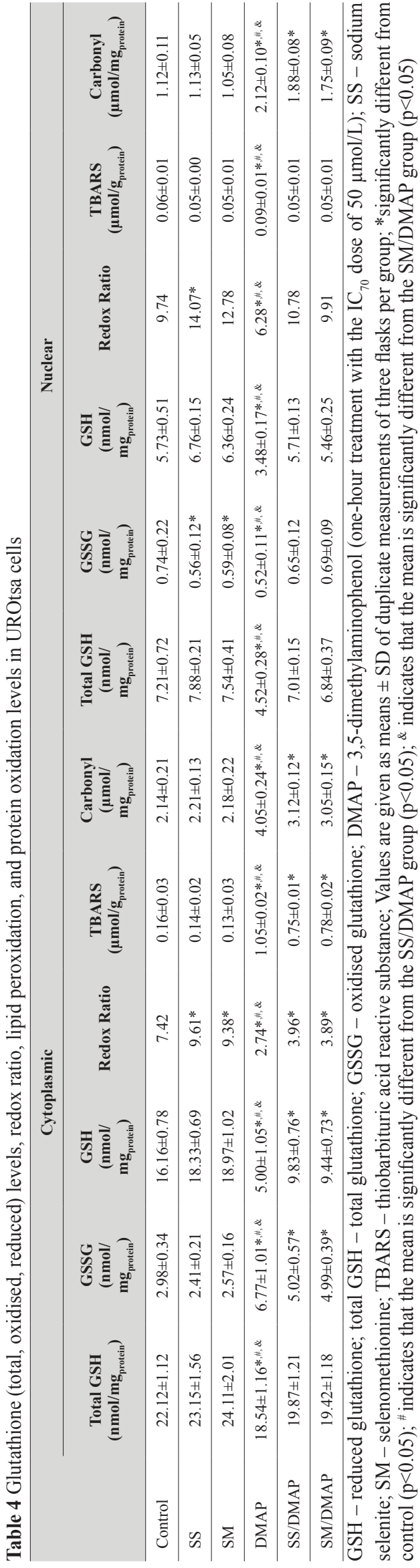

SM/DMAP groups were still significantly higher than in control (4.7 and 4.8 times, respectively). Nuclear lipid peroxidation was 1.5 times higher in the DMAP group than control $(p<0.05)$. In the SS/DMAP and SM/DMAP it was restored to control levels.

Increased lipid peroxidation is known to facilitate protein oxidation. The best biomarker of protein oxidation is protein carbonylation (33). However, protein oxidation can arise independently $(33,34)$, and protein peroxides can induce lipid oxidation via radical-mediated reactions (33-35). We found that cytoplasmic and nuclear protein oxidation increased significantly in 3,5-DMAP treated cells as evidenced by increases in protein carbonyl levels (Table 4). 3,5-DMAP treatment increased cytoplasmic carbonyl levels (indicator of protein oxidation) 1.9 times compared to control. Pretreatment with SS and SM reduced cytoplasmic protein oxidation, but it remained significantly higher than in control (1.5 times in the SS/DMAP group and 1.4 times higher in the SM/DMAP). Nuclear carbonyl levels were also 1.9 times higher in the DMAP group than control cells, and remained significantly higher in the SS/ DMAP and SM/DMAP groups (1.7 and 1.6 times, respectively).

Our results suggest that protein carbonyl levels increased due to increases in lipid peroxidation. Similar results were reported for CHO AS52 and AA8 cells (12-14). All these studies clearly show that increases in lipid peroxidation may significantly lead to protein oxidation (33-35), and oxidised proteins lose their ability to interact with cellular processes, which may also lower the activities of enzymatic antioxidants.

\section{CometChip}

Overproduction of ROS and increased lipid peroxidation combined with insufficient antioxidant enzymes causes different types of DNA damage (36). Even though the major DNA lesions are caused by direct oxidation of DNA bases, modifications caused by lipid peroxidation products, MDA in particular, may damage DNA nearly as much as direct base oxidation. MDA reacts with guanine, adenine, and cytosine to form cyclic pirymido- $[1,2 \alpha]$ purine- $10(3 \mathrm{H})$ one-2'-deoxyribose (M1dG) adduct, the major MDA-DNA adduct in rodent and human tissues. M1dG induces transversions (particularly to $\mathrm{T}$ ) and transitions (especially to A) with a frequency comparable with that of 8-oxoG in Escherichia coli $(35,36)$.

Figure 3 shows DNA damage induced by 3,5-DMAP $(50 \mu \mathrm{mol} / \mathrm{L})$. Neither SS nor SM alone reduced the olive tail moment (OTM), whereas 3,5-DMAP significantly increased both the \%tail DNA (25\%) and OTM (24\%) compared to control. Pretreatment with SS and SM significantly lowered \%tail DNA (24\% and 26\%, respectively) as well as OTM ( $17 \%$ and $20 \%$, respectively). The neutral comet assay did not reveal any changes in \%tail 


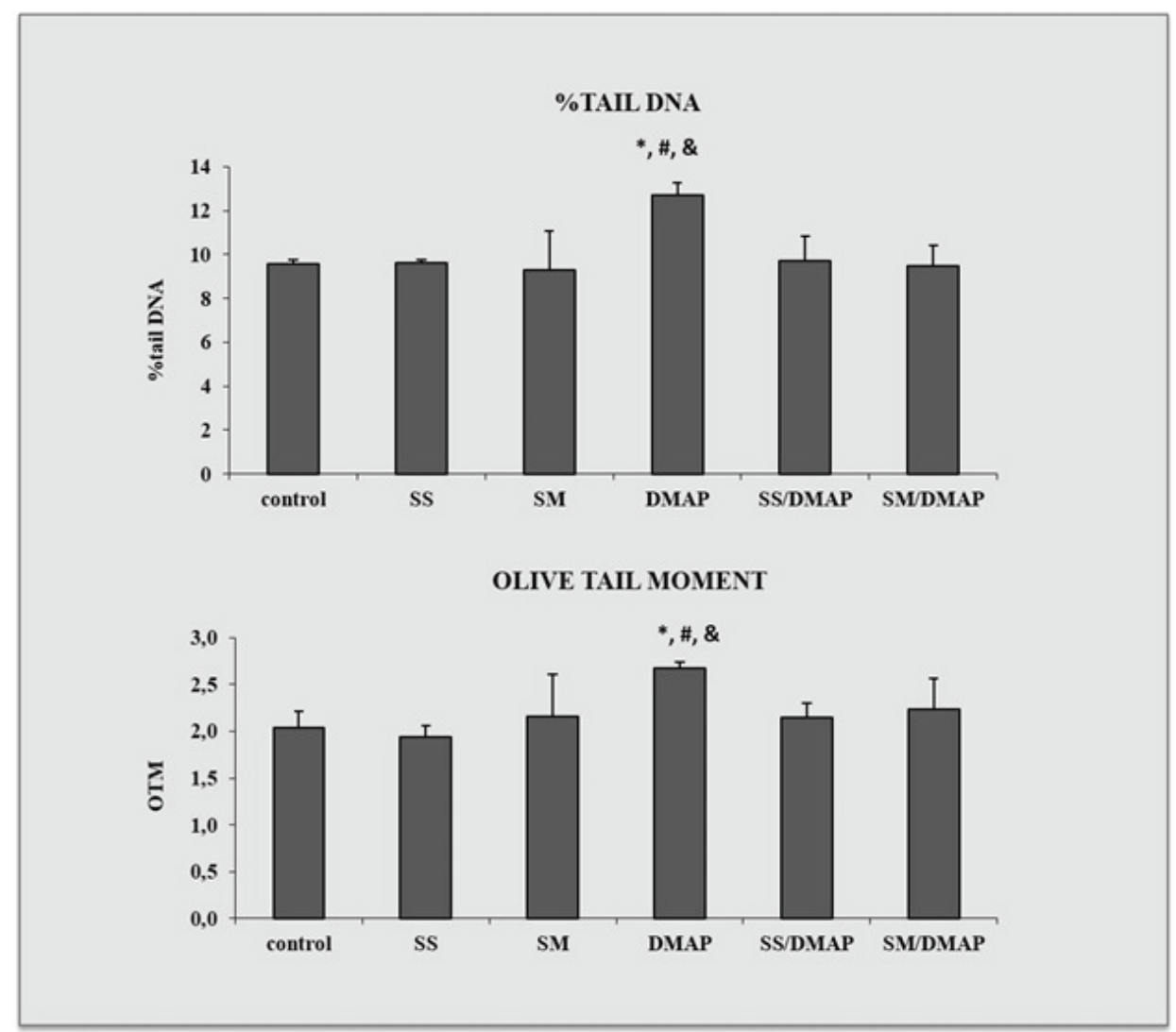

Figure $3 \%$ tail DNA and OTM values obtained with the alkaline CometChip assay; OTM - olive tail moment; DMAP 3,5-dimethylaminophenol ( $\mathrm{IC}_{70}$ dose of $50 \mu \mathrm{mol} / \mathrm{L}$ ); $\mathrm{SM}$ - selenomethionine; $\mathrm{SS}$ - sodium selenite; * significantly higher than in control; ${ }^{\#}$ significantly higher than in SS/DMAP; ${ }^{*}$ significantly higher than in SM/DMAP

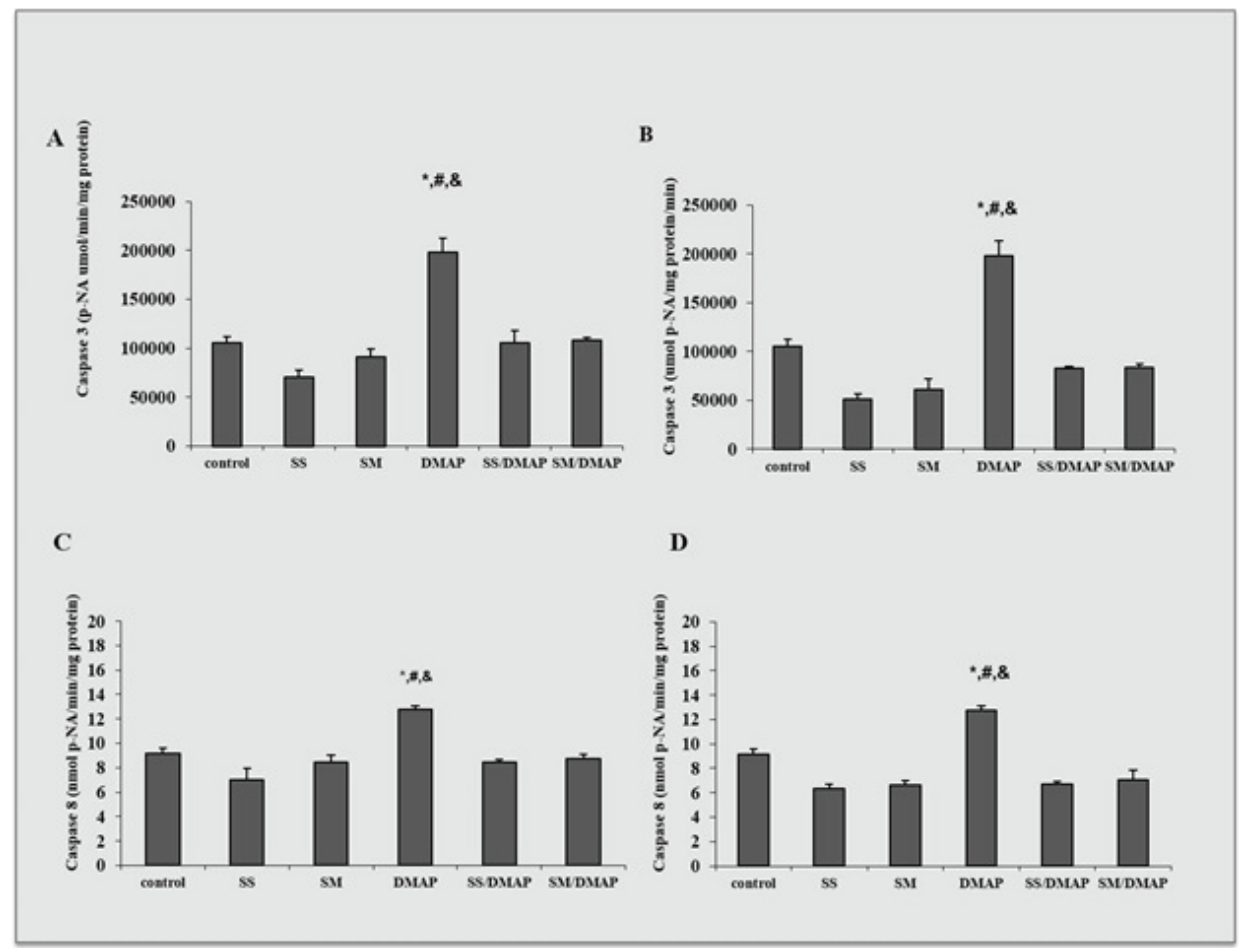

Figure 4 Caspase 3 and caspase 8 activities in the study groups. Values are given as means \pm SD of duplicate measurements of three flasks per group; A - Caspase 3 activity in the groups pretreated with SS or SM for $24 \mathrm{~h}$; B - Caspase 3 activity in the groups pretreated with SS or SM for $72 \mathrm{~h} ; \mathrm{C}-$ Caspase 8 activity in the groups pretreated with SS or SM for $24 \mathrm{~h}$; D - Caspase 8 activity in the groups pretreated with SS or SM for $72 \mathrm{~h}$ ); DMAP - 3,5-dimethylaminophenol ( $\mathrm{IC}_{70}$ dose of $50 \mu \mathrm{mol} / \mathrm{L}$ ); SM - selenomethionine; SS - sodium

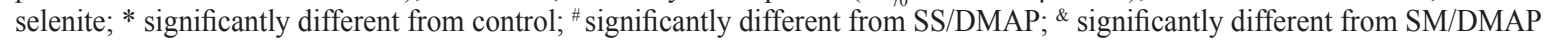


DNA and OTM after 3,5-DMAP treatment, perhaps because of its lower sensitivity to the alkaline comet assay.

Significantly increased \%tail DNA and OTM in the 3,5-DMAP-treated cells confirm its damaging potential in the DNA. Our previous study (14) showed a similar decrease in DNA damage in CHO AS52 cells pretreated with SS and SM. Other studies also confirm their protective effect against DNA damage induced by a variety of compounds, including phthalates.

The results of CometChip clearly show that 3,5-DMAP causes DNA damage, possibly through the oxidation of DNA bases. Studies on a wider spectrum (with mechanistic data) than ours should be able to show what types of DNA damage 3,5-DMAP exposure can cause. As most of the DNA damage is related to the oxidation of guanine (8-oxodeoxyguanine formation), measurements of DNA repair protein levels [8-oxoguanine glycosylase (OGG1) in particular] should be able to show how 3,5-DMAP affects the base excision repair pathway.

\section{Caspase 3 and 8 activities}

Caspases are a family of protease enzymes playing essential roles in apoptosis. Caspase 8 is an initiator caspase that leads to the activation of caspase 3 as an executioner caspase. Figure 4 summarises cellular caspase 3 and caspase 8 activities in our study. 3,5-DMAP caused a significant $(87 \%)$ increase in caspase 3 activity, while pretreatment with SS and SM lowered it $46 \%$ and $45 \%(\mathrm{p}<0.05)$, respectively in the first $24 \mathrm{~h}$. After $72 \mathrm{~h} \mathrm{SS}$ lowered it $58 \%$ and SM $57 \%$.

Caspase 8 activity rose $39 \%$ in the DMAP group in respect to control, while pretreatment with SS lowered it $33 \%$ and with SM $31 \%$ after $24 \mathrm{~h}$ compared to DMAP alone $(\mathrm{p}<0.05)$. After $72 \mathrm{~h}, \mathrm{SS}$ pretreatment also resulted in a significant decrease in caspase 8 activity. Due to a high standard deviation in the SM pretreatment group, this drop was not significant.

Apoptosis is characterised by lower cellular GSH content (37), and our findings of reduced GSH levels and apoptosis induction in 3,5-DMAP-treated cells confirm that association. They also confirm the protective effects of the tested selenocompounds against cell death caused by this alkyl aniline metabolite. Similar results were previously reported for CHO AA8 and AS52 cells (12-14).

Our results clearly point to 3,5 -DMAP as the cause of apoptosis in human urothelial cells. However, other forms of cell death, autophagy in particular (as well as different autophagic markers), should also be investigated in order to determine the mechanism of cell death caused by alkyl anilines.

In conclusion, this is the first study that shows the toxic effects of 3,5-DMAP on human urothelial cells. As low selenium status is suggested to be one of the most important factors in the emerging of bladder cancer, protective effects of both organic and inorganic selenium were also evaluated.
Both selenocompounds were found to be protective against the cytotoxic, genotoxic, and ROS-producing effects of 3,5-DMAP, which confirmed the importance of selenium status. Moreover, we have observed that 3,5-DMAP induced apoptosis can be prevented by selenium supplementation. Our future aim is to conduct in vivo studies that can provide more mechanistic information on the mode of action of 3,5-DMAP.

\section{REFERENCES}

1. World Cancer Research Fund - American Institute of Cancer Research. Bladder cancer statistics [displayed 18 January 2019]. Available at https://www.wcrf.org/dietandcancer/ cancer-trends/bladder-cancer-statistics

2. Reszka E. Selenoproteins in bladder cancer. Clin Chim Acta 2012;413:847-54. doi: 10.1016/j.cca.2012.01.041

3. Wu JT, Han BM, Yu SQ, Wang HP, Xia SJ. Androgen receptor is a potential therapeutic target for bladder cancer. Urology 2010;75:820-7. doi: 10.1016/j.urology.2009.10.041

4. Ferlay J, Bray F, Sankila R, Parkin DM. EUCAN: Cancer Incidence, Mortality and Prevalence in the European Union 1998, version 5.0. IARC Cancer Base No. 4. Lyon: IARC Press; 1999.

5. Malats N, Real FX. Epidemiology of bladder cancer. Hematol Oncol Clin North Am 2015;29:177-89. doi: 10.1016/j. hoc.2014.10.001

6. Zeegers MPA, Kellen E, Buntinx F, van den Brandt PA. The association between smoking, beverage consumption, diet and bladder cancer: a systematic literature review. World J Urol 2004;21:392-401. doi: 10.1007/s00345-003-0382-8

7. Carreón T, Hein MJ, Hanley KW, Viet SM, Ruder AM. Bladder cancer incidence among workers exposed to o-toluidine, aniline and nitrobenzene at a rubber chemical manufacturing plant. Occup Environ Med 2014;71:175-82. doi: 10.1136/oemed-2013-101873

8. Government of Canada, Health and Welfare Canada, Environment Canada. Priority Substances List Assessment Report - 3,5-Dimethylaniline, 1993 [displayed 18 January 2019]. Available at https://www.canada.ca/content/dam/hcsc/migration/hc-sc/ewh-semt/alt_formats/hecs-sesc/pdf/ pubs/contaminants/psl1-1sp1/3_5_dimethylaniline/3_5_ dimethylaniline-eng.pdf

9. Vinceti M, Filippini T, Del Giovane C, Dennert G, Zwahlen M, Brinkman M, Zeegers MP, Horneber M, D'Amico R, Crespi CM. Selenium for preventing cancer. Cochrane Database Syst Rev 2018;1:CD005195. doi:10.1002/14651858. CD005195.pub4.

10. Castelao JE, Yuan JM, Skipper PL, Tannenbaum SR, GagoDominguez M, Crowder JS, Ross RK, Yu MC. Gender- and smoking-related bladder cancer risk. J Natl Cancer Inst 2001;93:538-45. doi: 10.1093/jnci/93.7.538

11. Skipper PL, Trudel LJ, Kensler TW, Groopman JD, Egner PA, Liberman RG, Wogan GN, Tannenbaum SR. DNA adduct formation by 2,6-dimethyl-, 3,5-dimethyl, and 3-ethylaniline in vivo in mice. Chem Res Toxicol 2004;19:1086-90. doi: 10.1021/tx060082q

12. Chao MW, Erkekoglu P, Tseng CY, Ye W, Trudel LJ, Skipper PL, Tannenbaum SR, Wogan GN. Intracellular generation of ROS by 3,5-dimethylaminophenol: persistence, cellular 
response, and impact of molecular toxicity. Toxicol Sci 2014;141:300-13. doi: 10.1093/toxsci/kfu127

13. Chao MW, Erkekoglu P, Tseng CY, Ye W, Trudel LJ, Skipper PL, Tannenbaum SR, Wogan GN. Protective effects of ascorbic acid against the genetic and epigenetic alterations induced by 3,5-dimethylaminophenol in AA8 cells. J Appl Toxicol 2015;35:466-77. doi: 10.1002/jat.3046

14. Erkekoglu P, Chao MW, Ye W, Ge J, Trudel LJ, Skipper PL, Kocer-Gumusel B, Engelward BP, Wogan GN, Tannenbaum SR. Cytoplasmic and nuclear toxicity of 3,5-dimethylaminophenol and potential protection by selenocompounds. Food Chem Toxicol 2014;72:98-110. doi: 10.1016/j.fct.2014.06.031

15. Martindale JL, Holbrook NJ. Cellular response to oxidative stress: signaling for suicide and survival. J Cell Physiol 2002;192:1-15. doi: 10.1002/jcp.10119

16. Al-Zalabani AH, Stewart KF, Wesselius A, Schols AM, Zeegers MP. Modifiable risk factors for the prevention of bladder cancer: a systematic review of meta-analyses. Eur J Epidemiol 2016;31:811-51. doi: 10.1007/s10654-016-0138-6

17. American Cancer Society. Key Statistics for Bladder Cancer [displayed 18 January 2019]. Available at http://www.cancer org/cancer/bladdercancer/detailedguide/bladder-cancer-keystatistics

18. Flohé L, Gunzler WA. Assays of glutathione peroxidase. Methods Enzymol 1984;105:114-21. doi: 10.1016/S00766879(84)05015-1

19. Arnér ES, Zhong L, Holmgren A. Preparation and assay of mammalian thioredoxin and thioredoxin reductase. Methods Enzymol 1999;300:226-39. doi: 10.1016/S00766879(99)00129-9

20. Erkekoglu P, Rachidi W, De Rosa V, Giray B, Favier A, Hincal F. Protective effect of selenium supplementation on the genotoxicity of di(2-ethylhexyl)phthalate and mono(2ethylhexyl)phthalate treatment in LNCaP cells. Free Radic Biol Med 2010;49:559-66. doi: 10.1016/j. freeradbiomed.2010.04.038

21. Erkekoglu P, Rachidi W, Yuzugullu OG, Giray B, Favier A, Ozturk M, Hincal F. Evaluation of cytotoxicity and oxidative DNA damaging effects of di(2-ethylhexyl)-phthalate (DEHP) and mono(2-ethylhexyl)-phthalate (MEHP) on MA-10 Leydig cells and protection by selenium. Toxicol Appl Pharmacol 2010;248:52-62. doi: 10.1016/j.taap.2010.07.016

22. Bhamre S, Whitin JC, Cohen HJ. Selenomethionine does not affect PSA secretion independent of its effect on $\mathrm{LNCaP}$ cell growth. Prostate 2003;54:315-21. doi: 10.1002/pros. 10184

23. Pourkhalili N, Hosseini A, Nili-Ahmadabadi A, Rahimifard M, Navaei-Nigjeh M, Hassani S, Baeeri M, Abdollahi M. Improvement of isolated rat pancreatic islets function by combination of cerium oxide nanoparticles/sodium selenite through reduction of oxidative stress. Toxicol Mech Methods. 2012;22:476-82. doi: 10.3109/15376516.2012.673093.

24. Mansur DB, Hao H, Gladyshev VN, Korotkov KV, Hu Y, Moustafa ME, El-Saadani MA, Carlson BA, Hatfield DL,
Diamond AM. Multiple levels of regulation of selenoprotein biosynthesis revealed from the analysis of human glioma cell lines. Biochem Pharmacol 2000;60:489-97. PubMed PMID: 10874123

25. Fontenelle LS, Feitosa MM, Silva Morais JB, Soares Severo J, Coelho de Freitas TE, Batista Beserra J, Henriques GS, do Nascimento Marreiro D. The role of selenium in insulin resistance. Braz J Pharm Sci 2018;54:e00139. doi: http:// dx.doi.org/10.1590/s2175-97902018000100139.

26. Habig WH, Pabst MJ, Jakoby WB. Glutathione S-transferases. The first enzymatic step in mercapturic acid formation. J Biol Chem 1974;249:7130-9. PMID: 4436300

27. Richard MJ, Portal B, Meo J, Coudray C, Hadjian A, Favier A. Malondialdehyde kit evaluated for determining plasma and lipoprotein fractions that react with thiobarbituric acid. Clin Chem 1992;38:704-9. PMID: 1582024

28. Davies MJ. Protein oxidation and peroxidation. Biochem J 2016;473:805-25. doi: 10.1042/BJ20151227

29. Krieg RC, Dong Y, Schwamborn K, Knuechel R. Protein quantification and its tolerance for different interfering reagents using the BCA-method with regard to 2D SDS PAGE. J Biochem Biophys Methods 2005;65:13-9. doi: 10.1016/j.jbbm.2005.08.005

30. Erkekoglu P. Protection studies by antioxidants using single cell gel electrophoresis (comet assay) In: Magdeldin S, editor. Gel electrophoresis - advanced techniques. Rijeka: InTech; 2012. p. 413-46.

31. Wood DK, Weingeist DM, Bhatia SN, Engelward BP. Single cell trapping and DNA damage analysis using microwell arrays. Proc Natl Acad Sci USA 2010;107:10008-13. doi: 10.1073/pnas. 1004056107

32. Dickinson DA, Forman HJ. Cellular glutathione and thiols metabolism. Biochem Pharmacol 2002;64:1019-26. doi: 10.1016/S0006-2952(02)01172-3

33. Haribabu A, Reddy VS, Pallavi Ch, Bitla AR, Sachan A, Pullaiah P, Suresh V, Rao PV, Suchitra MM. Evaluation of protein oxidation and its association with lipid peroxidation and thyrotropin levels in overt and subclinical hypothyroidism. Endocrine 2013;44:152-7. doi: 10.1007/s12020-012-9849-y

34. Gebicki S, Gebicki JM. Crosslinking of DNA and proteins induced by protein hydroperoxides. Biochem J 1999;338:62936. PMCID: PMC1220096

35. Esterbauer H, Eckl P, Ortner A. Possible mutagens derived from lipids and lipid precursors. Mutat Res 1990;238:223-33. doi: 10.1016/0165-1110(90)90014-3

36. Marnett LJ. Lipid peroxidation-DNA damage by malondialdehyde. Mutation Res 1999;424:83-95. doi: 10.1016/S0027-5107(99)00010-X

37. Ballatori N, Krance SM, Notenboom S, Shi S, Tieu K, Hammond CL. Glutathione dysregulation and the etiology and progression of human diseases. Biol Chem 2009;390:191214. doi: $10.1515 /$ BC. 2009.033 . 


\section{Antioksidansi i spojevi selenija inhibiraju toksično djelovanje 3,5-dimetilaminofenola na epitelne bubrežne stanice u ljudi}

Izloženost alkilnim anilinima može uzrokovati rak mokraćnoga mjehura, koji je drugi po redu po učestalosti raka mokraćnospolnog sustava. 3,5-dimetilanilin često se rabi u industrijskoj proizvodnji, a istraživanja njegova primarnog metabolita, 3,5-dimetilaminofenola (3,5-DMAP), pokazuju da on uzrokuje oksidacijski stres i promjene u aktivnosti antioksidacijskih enzima te u konačnici dovodi do smrti raznih stanica u sisavaca. Dosad, međutim, nije provedeno nijedno istraživanje njegovih izravnih učinaka na epitelne stanice mokraćnoga mjehura i bubrega u ljudi. Za spojeve selenija smatra se da smanjuju oksidacijski stres različitih kemikalija te da dopuna prehrane selenijem smanjuje rizik od raka mokraćnoga mjehura. Primarni je cilj ovoga istraživanja bio utvrditi može li organski spoj selenija selenometionin (SM, $10 \mu \mathrm{mol} / \mathrm{L})$, odnosno anorganski spoj natrijev selenit (SS, $30 \mathrm{nmol} / \mathrm{L}$ ], smanjiti oksidacijski stres, oštećenje DNA i apoptozu u UROtsa stanicama izloženima 3,5-dimetilaminofenolu. Jednosatna izloženost stanica 3,5-DMAP-u dovela je do povećanja razina reaktivnih kisikovih spojeva (ROS), lipidne peroksidacije, oksidacije bjelančevina te do promjena u aktivnosti antioksidacijskih enzima u staničnoj citoplazmi i jezgri, ovisno o primijenjenoj dozi. Osim toga, komet-testom su utvrđeni jednolančani, ali ne i dvolančani lomovi DNA. Također, 3,5-DMAP uzrokovao je apoptozu stanica. Oba su spoja selenija pružila djelomičnu zaštitu od njegova toksičnoga djelovanja. Nedostatak selenija pri izloženosti alkilnim anilinskim spojevima stoga može odigrati značajnu ulogu u nastanku raka mokraćnog mjehura. Potrebna su daljnja istraživanja mehanizama djelovanja selenija u njegovu sprječavanju.

KLJUČNE RIJEČI: alkilni anilini; citotoksičnost; genotoksičnost; reaktivni kisikovi spojevi; natrijev selenit; selenij; selenometionin 